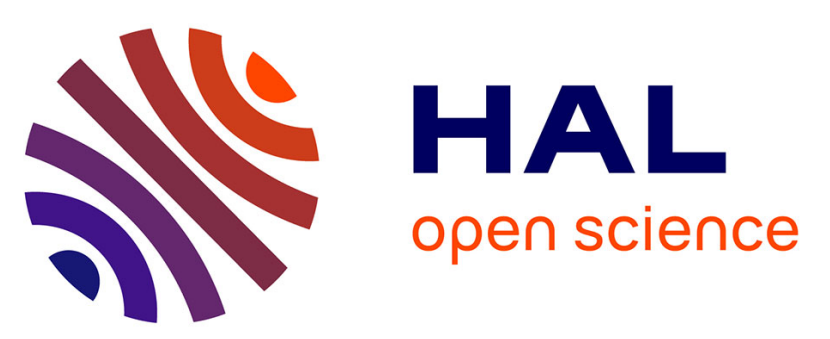

\title{
Characterization of the S locus genes, SLG and SRK, of the Brassica S3 haplotype: identification of a membrane-localized protein encoded by the $\mathrm{S}$ locus receptor kinase gene
}

Valerie Delorme, Jean-Loic Giranton, Yves Hatzfeld, Aline Friry, Philippe

Heizmann, Maria Jose Ariza, Christian Dumas, Thierry Gaude, J. Mark Cock

\section{To cite this version:}

Valerie Delorme, Jean-Loic Giranton, Yves Hatzfeld, Aline Friry, Philippe Heizmann, et al.. Characterization of the S locus genes, SLG and SRK, of the Brassica S3 haplotype: identification of a membrane-localized protein encoded by the S locus receptor kinase gene. Plant Journal, 1995, 7 (3), pp.429-440. 10.1046/j.1365-313x.1995.7030429.x . hal-03086441

\section{HAL Id: hal-03086441 \\ https://cnrs.hal.science/hal-03086441}

Submitted on 5 Jan 2021

HAL is a multi-disciplinary open access archive for the deposit and dissemination of scientific research documents, whether they are published or not. The documents may come from teaching and research institutions in France or abroad, or from public or private research centers.
L'archive ouverte pluridisciplinaire HAL, est destinée au dépôt et à la diffusion de documents scientifiques de niveau recherche, publiés ou non, émanant des établissements d'enseignement et de recherche français ou étrangers, des laboratoires publics ou privés. 


\section{Characterization of the $S$ locus genes, SLG and SRK, of the Brassica $S_{3}$ haplotype: identification of a membrane-localized protein encoded by the $S$ locus receptor kinase gene}

\author{
Valérie Delorme ${ }^{\dagger}$, Jean-Loic Giranton ${ }^{\dagger}$, Yves Hatzfeld, \\ Aline Friry, Philippe Heizmann, María José Ariza, \\ Christian Dumas, Thierry Gaude and J. Mark Cock* \\ Reconnaissance Cellulaire et Amélioration des Plantes, \\ UMR 9938 CNRS-INRA-ENSL, Ecole Normale Supérieure \\ de Lyon, 46 allée d'Italie, 69364 Lyon Cedex 07, France
}

\section{Summary}

The $S$ locus, which controls the self-incompatibility response in Brassica, has been shown to contain at least two genes. SLG encodes a secreted S locus glycoprotein whilst $S R K$ encodes a putative $S$ locus receptor kinase. SRK has been shown potentially to encode a functional kinase and genetic evidence indicates that this gene is essential for the self-incompatibility response. Here the characterization of the SRK and SLG genes of a Brassica line homozygous for the $S_{3}$ haplotype is described. A 120 $\mathrm{kDa}$ glycoprotein was identified in stigmas and several lines of evidence indicated that this protein is encoded by the $\mathrm{SRK}_{3}$ gene. First, the $120 \mathrm{kDa}$ glycoprotein was recognized by antibodies raised against peptides based on the $\mathrm{SRK}_{3}$ gene sequence. Secondly, this protein is polymorphic and, in an $F_{2}$ population segregating for the $S_{3}$ haplotype, was expressed only in plants possessing the $S_{3}$ haplotype. Thirdly, the $120 \mathrm{kDa}$ protein was expressed specifically in stigmas. Finally, the $120 \mathrm{kDa}$ protein was only extracted from stigmas in the presence of detergent indicating that it is anchored in the membrane. SRK has been predicted to encode a transmembrane glycoprotein based on the deduced amino acid sequence. Located on the membrane, SRK is in a position to interface between an extracellular recognition event between pollen and pistil and an intracellular signal transduction pathway which initiates the self-incompatibility response.

\section{Introduction}

Self-incompatibility (SI) in Brassica involves a process of specific cell-cell interaction between pollen and the papillar cells of the stigma. The $\mathrm{SI}$ response is controlled by a

Received 5 August 1994; revised 7 November 1994; accepted 25 November 1994.

*For correspondence (fax +3372728600 ).

${ }^{\dagger}$ These authors contributed equally to this study. single, highly polymorphic locus, the $S$ locus. Normally, when the pollen grain and the papillar cell express the same $S$ allele, fertilization is rapidly aborted either because the pollen does not germinate or because the pollen tube does not penetrate the stigma surface. Efforts to understand the molecular mechanism of the rejection reaction have concentrated on the identification of genes linked to the $S$ locus. The two genes which have been identified to date encode the $S$ locus glycoprotein (SLG; Nasrallah et al., 1987) and a putative $S$ locus receptor kinase (SRK; Stein et al., 1991). SLG is an abundant stigma protein which is highly polymorphic in different $S$ locus genotypes (Nasrallah et al., 1987) consistent with it playing a role in the SI response. SLG gene transcription has also been detected in anthers but at a much lower level than in the stigma (Sato et al., 1991). The SRK gene is predicted to encode a transmembrane receptor protein kinase with an extracellular domain (the $S$ domain) that is highly similar to SLG, a single transmembrane domain and an intracellular kinase domain. Although the SRK gene has not yet been shown to be expressed at the protein level in vivo, the kinase domain has been shown to be potentially functional by expression in Escherichia coli (Goring and Rothstein, 1992; Stein and Nasrallah, 1993). Like SLG, SRK appears to be highly polymorphic and is expressed in both pistils and, at a lower level, in anthers. SLG and SRK are members of a multigene family. Two other members of this family, the $S$ locus-related genes $S L R 1$ and $S L R 2$, have also been shown to be expressed specifically in stigmas (Boyes et al., 1991; Lalonde et al., 1989).

Cloning and sequencing of a number of SLG alleles has demonstrated a divergence of up to $36 \%$ at the amino acid level. $S L G$ alleles have been divided into two classes based on the immunoreactivity of their products with an antibody raised against $\mathrm{SLG}_{6}$ (Kandasamy et al., 1989) and on sequence comparison. Interactions between $S$ alleles can involve co-dominance or dominance/recessiveness in the stigma or in the pollen. Class I alleles tend to be dominant and to correspond a strong SI reaction whereas class II alleles tend to be recessive and associated with a weak SI response. Interestingly, when the deduced amino acid sequence of an SLG is compared with that of the $S$ domain of SRK from the same $S$ haplotype, sequence similarity is generally greater than $84 \%$ (Goring and Rothstein, 1992; Goring et al., 1993; Stein et al., 1991). SLG and SRK genes within an $S$ haplotype, therefore, appear to have co-evolved 
despite the generation of a high level of polymorphism between different $S$ haplotypes indicating that there may be a functional interaction between the two proteins.

In this study, we have identified the SLG and SRK genes of the class I, pollen-dominant $S_{3}$ haplotype. Antibody probes have been used to show that both SLG and SRK are expressed in the stigma. The SRK gene was shown to encode a $120 \mathrm{kDa}$, membrane-associated glycoprotein. The data presented here are consistent with the proposed role for SRK, perhaps acting in combination with SLG, in coupling pollen-stigma recognition to an intracellular signal transduction pathway involving protein phosphorylation (Stein et al., 1991).

\section{Results}

Cloning and sequence analysis of the SLG and SRK genes of the $\mathrm{S}_{3}$ haplotype

The B. oleracea line P57 Si (described in Gaude et al., 1993) has recently been shown to be homozygous for the $S_{3}$ haplotype based on two criteria. First, P57 Si has been shown to exhibit an $S_{3}$ phenotype in cross-pollinations with tester lines carrying different $S$ alleles (Ockendon, personal communication). Secondly, the pattern of SLG isoforms detected by an anti-SLG antibody following separation of stigma proteins by IEF was the same for P57 Si as for an $S_{\boldsymbol{J}} / S_{3}$ tester line (Gaude, unpublished data). For the sake of clarity, P57 Si will be subsequently referred to simply as the $S_{3} / S_{3}$ homozygous line.

Cloning of cDNAs corresponding to the $S L G_{3}$ gene based on their hybridization to BS29-2 (SLG 29 CDNA; Trick and Flavell, 1989) and to an oligonucleotide derived from the $\mathrm{N}$-terminal, amino acid sequence of the $\mathrm{SLG}_{3}$ protein has been described (Gaude et al., 1993). One of these clones was sequenced (Figure 1) and was shown to be related to $S L G$ genes from other $S$ haplotypes by comparison with sequences in the database.

A mixed probe consisting of part of this CDNA and part of the $\mathrm{SRK}_{3} \mathrm{~S}$ domain obtained by PCR amplification from genomic DNA was used to screen a genomic library constructed from DNA of the $S_{3} / S_{3}$ homozygous line. Genomic clones corresponding to $S L G_{3}$ and $S R K_{3}$ were obtained. PCR

(a)

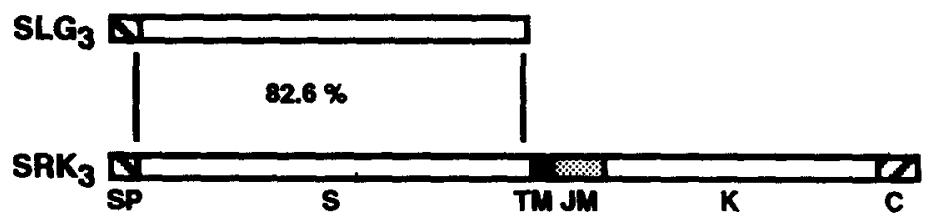

(b)

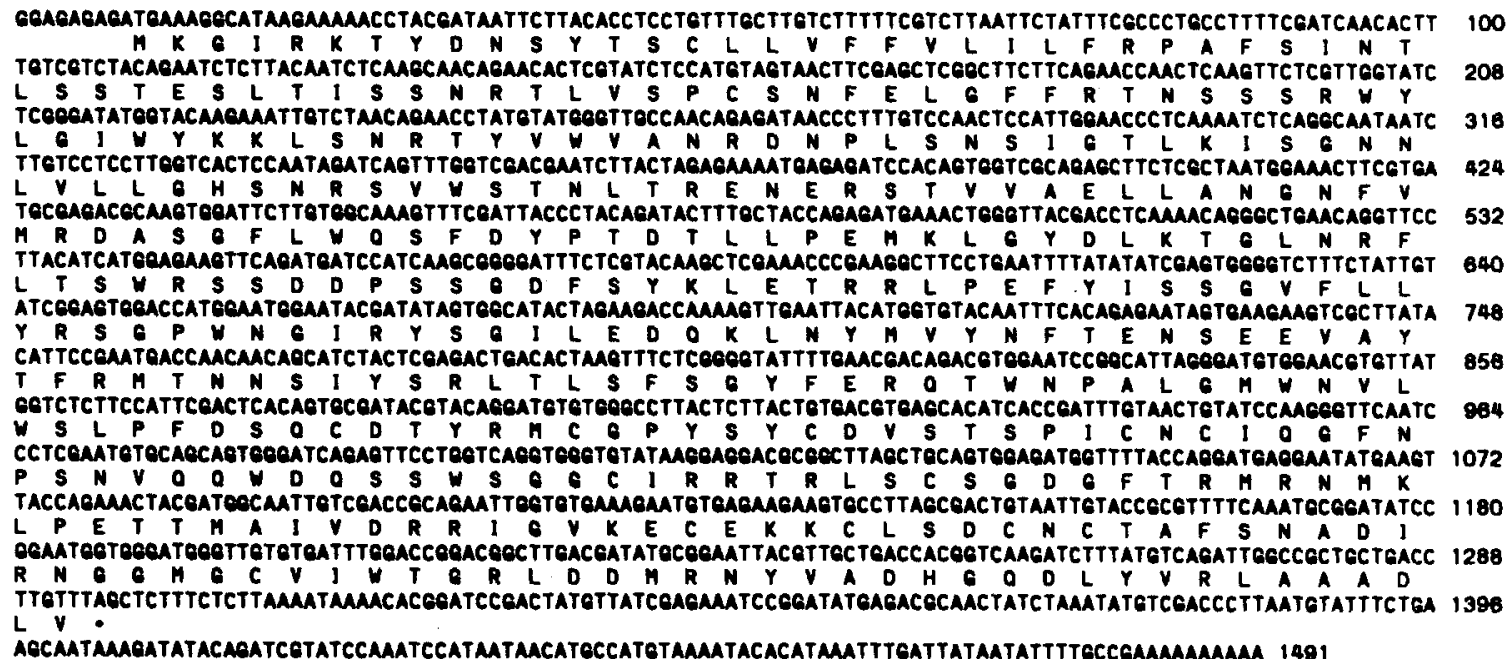

Figure 1. Sequence analysis of the $S L G_{3}$ and $S R K_{3}$ genes.

(a) Schematic representation of the predicted $S_{L} G_{3}$ and $S R K_{3}$ proteins showing the percentage similarity between $S$ domains. SP, signal peptide; $S$, $S$ domain; TM, transmembrane domain; JM, juxtamembrane domain; $K$, kinase domain; $C, C$-terminal domain.

(b and c) Nucleotide sequences of the $S L G_{3}$ cDNA and the $S R K_{3}$ gene. The deduced amino acid sequences of the SLG ${ }_{3}$ and $S R K_{3}$ proteins are shown below the coding sequences. Introns are indicated by lower case letters. Asterisks indicate termination codons at the end of each coding sequence and a termination codon in the first intron of $S R K_{3}$ described in the text. Sequences are numbered from the first base of the ATG initiation codon. SRK 3 polyadenylation sites, identified by RACE.PCR, are indicated with a dot. The EMBL Data Library accession numbers for the $S L G_{3} c D N A$ and the $S R K_{3}$ gene sequences are X79431 and $X 79432$, respectively. 


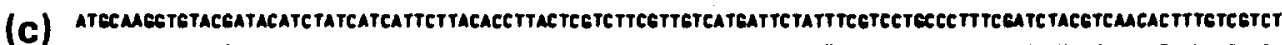
H O E V R I Y H H S Y T L L V V V A I L F R A L B I Y Y N T L 3 S

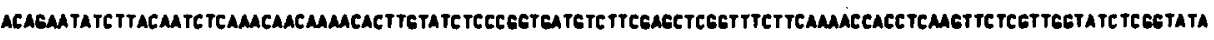

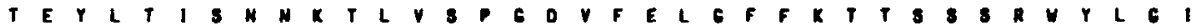
TEETACMGACATTETCCEACAGMACCTATETATEGATTECCAACACAGATAACCCTATATCCAACTCCACTEEAACCCTCMAMTCTCAGECMTAATCTTETCCTC * Y T L S D R Y Y V I N N D N P I S N S T E T L K I S E N N L V L

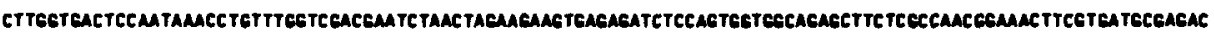

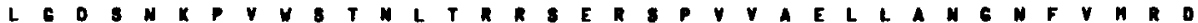

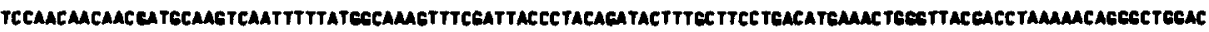
S N N D A S O F L O O F D Y P T O T L L D D K L G Y O L K T G L O

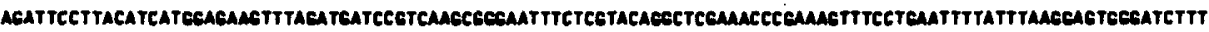

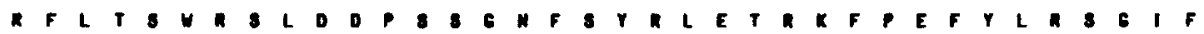

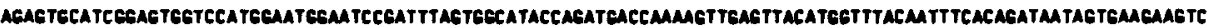

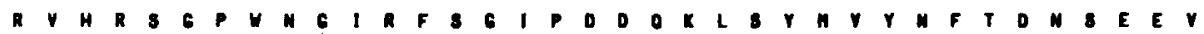

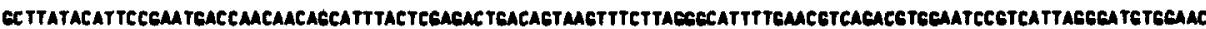

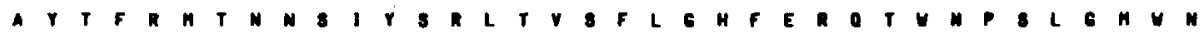

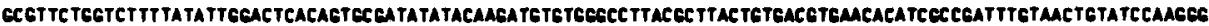

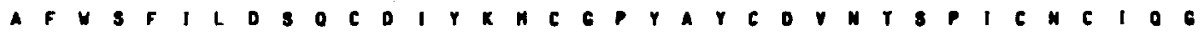

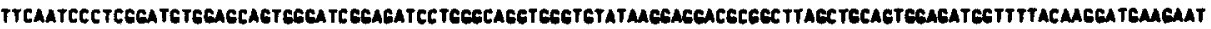

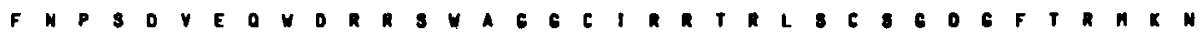

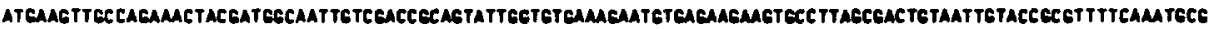

N K L P E T T N A I Y D R S I E Y K E C E K K C L S O C N C T A F S NA

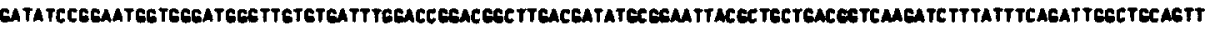

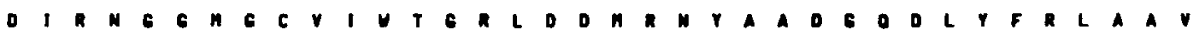

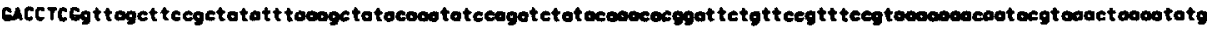

D L

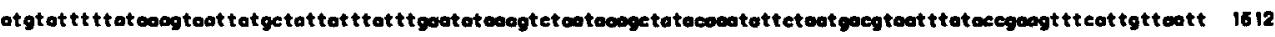

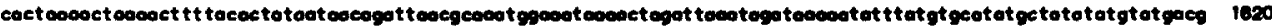

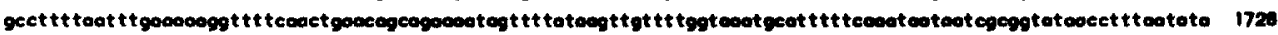

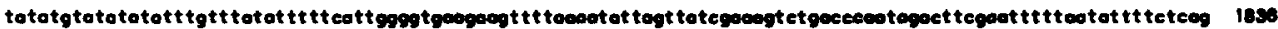

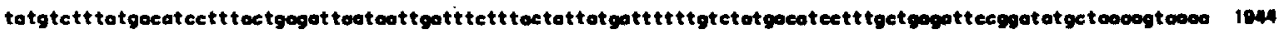

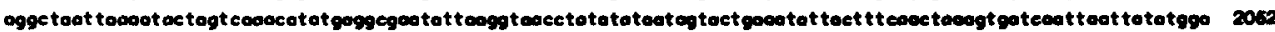

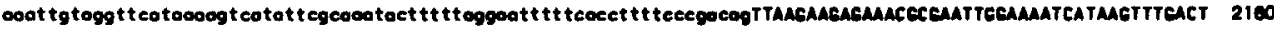

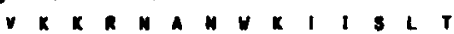

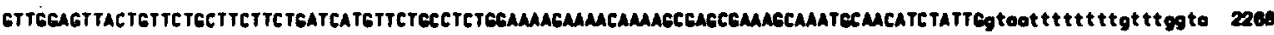
V $V$ I V L L L L I M F C L V K K K O K K A K A M A T

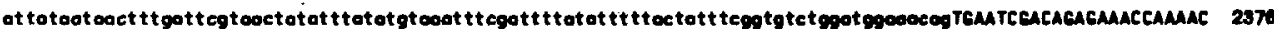
$\checkmark$ M 0 a $M$ O TTGCCTATCAACCCGATCGTACTATCAACCAACACACAGTTTTCTCMAGACAACAMATTCACGMCTCEAACTTCCATTCATACATTTCCAMACTCTTETCMACCT 24QA L P N G M V L S S K TE F E E E N K I E E L E L P L I D L E T V V K A

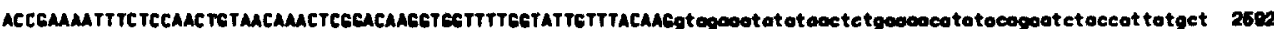

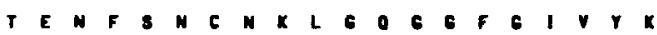

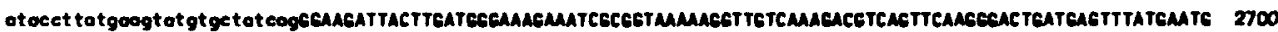
G R L L D E K E I A V K R L 8 K T 8 V O

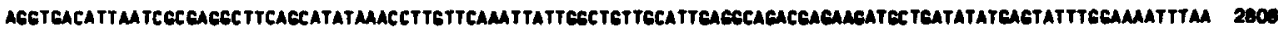
E V T L I A R L O

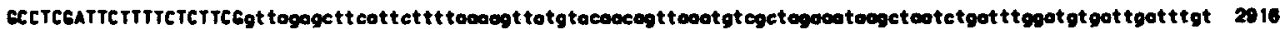
8 L D 3 F L F.

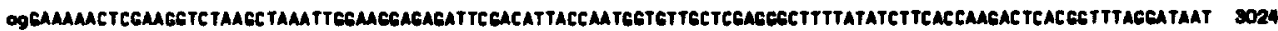

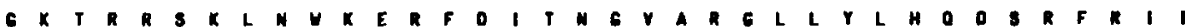

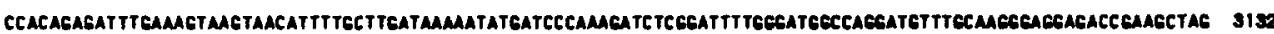

H R D L K V S N I L L D K N M I P K I S D F E N A I N F A R E E TEA

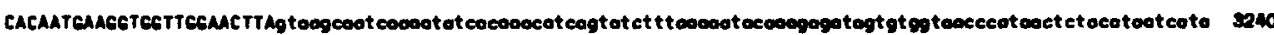

$T \times Y$ Y $Y$

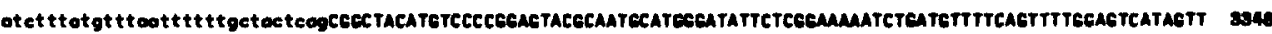
C Y D Y A H I F E E D V E E V I V

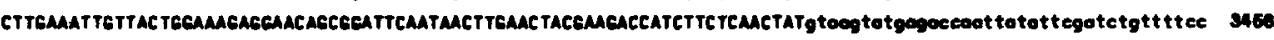
LE I V T E N N S G F M L Y E D H L L Y

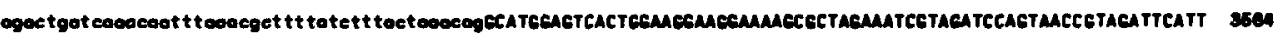
$A$ A H Y K E C K A L E I Y D P Y T V D 5 L

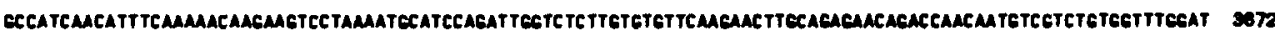

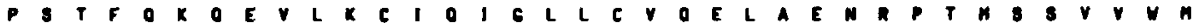

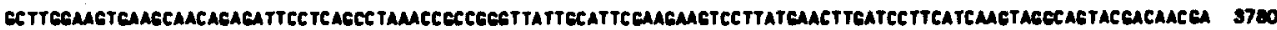

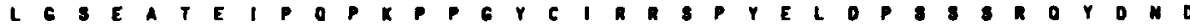

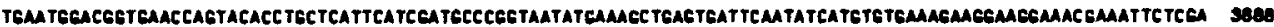

E W T Y M O Y T C S F I D A

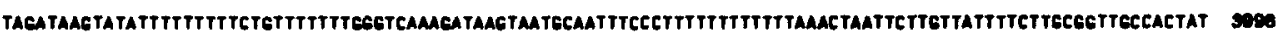

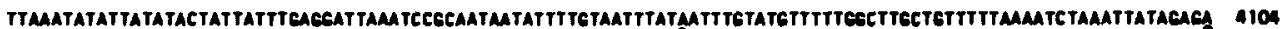

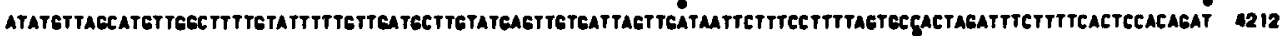
ACATAMCTCTTTMATTTCMATCMACTTTCATMATTTCATTA 


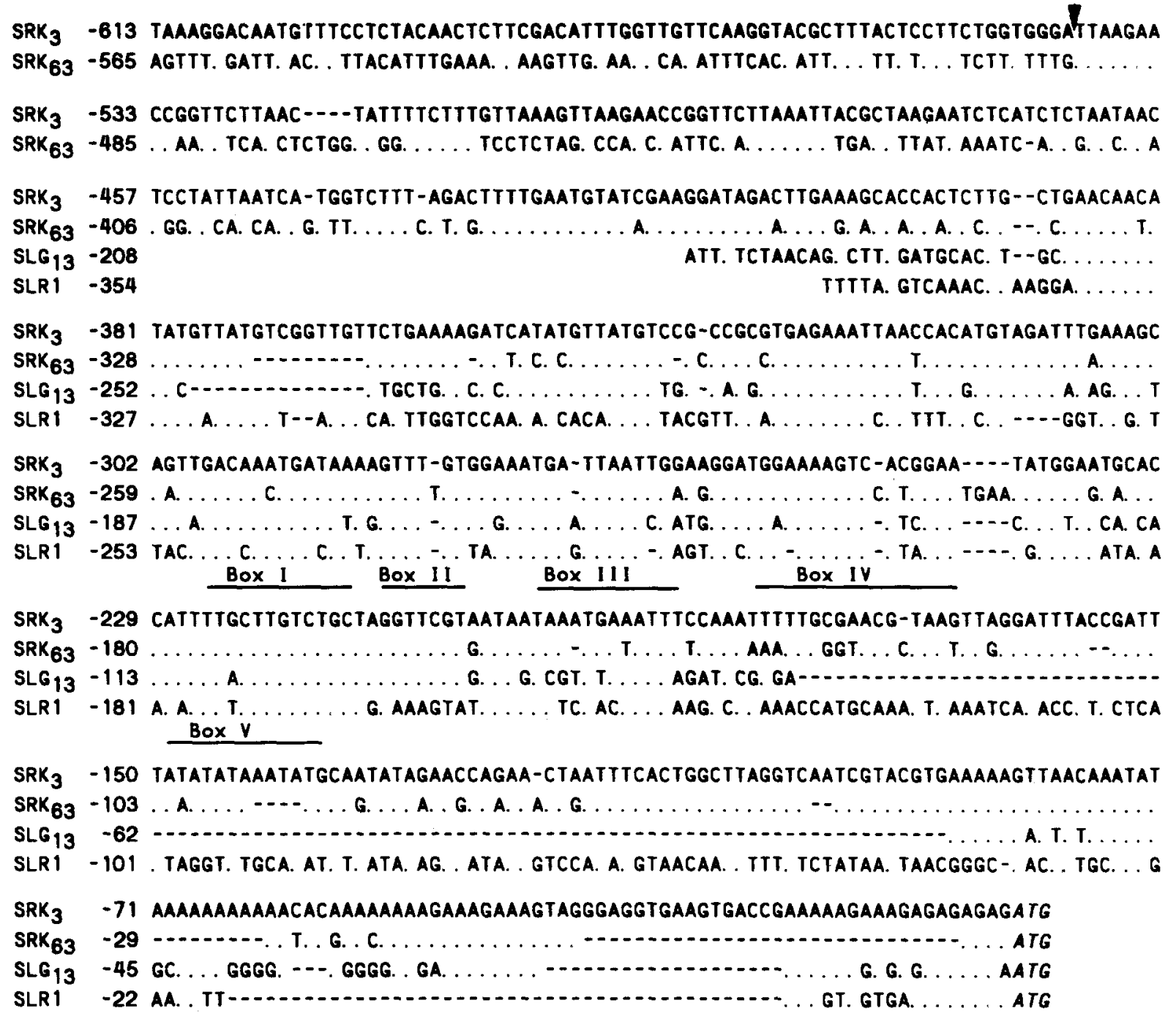

Figure 2. Nucleotide sequence of the $S R K_{3}$ promoter aligned with the promoter regions of the $S R K_{63}, S L G_{13}$ and $S L R 1$ yenes.

Dots indicate residues conserved with respect to the $S R K_{3}$ promoter, dashes represent gaps introduced to optimize alignment. Sequences are numbered from the first base of the ATG initiation codon which is shown in italics. Regions corresponding to the five boxes identified by Dzelzkalns et al. (1993) are underlined. The arrowhead marks the $5^{\prime}$ limit of the region conserved between the promoters of $S R K_{3}$ and $S R K_{63}$. The $S L G_{13}$ and $S L R 1$ promoter sequences are from Dzelzkalns et al. (1993), $S R K_{63}$ promoter: accession number Z18921.

amplification from the $S L G_{3}$ cDNA and genomic clones using oligonucleotides which prime from the $5^{\prime}$ and $3^{\prime}$ ends of the cDNA was used to show that the cDNA and genomic clones were co-linear and, therefore, that the $S L G_{3}$ gene contains no introns in this region (data not shown).

The $S R K_{3}$ gene was subcloned into a plasmid vector and DNA sequence was determined for a region of $5345 \mathrm{bp}$ (Figures 1c and 2). In order to identify the positions of the exons, an $\mathrm{SRK}_{3}$ CDNA was isolated by PCR amplification from stigma cDNA using oligonucleotides based on the $S_{R} K_{3}$ gene sequence (see Experimental procedures). Comparison of the $S R K_{3}$ gene and cDNA sequences revealed the same arrangement of seven exons separated by six introns (Figure 1c) as has been reported for the $S R K_{6}$ and $S R K_{2}$ genes (Stein et al., 1991). The positions of the introns in $S R K_{3}$ correspond exactly with those of $S R K_{6}$ and the sizes of corresponding introns are very similar. In addition, as has been found for $S R K_{6}$ and $S R K_{2}$ (Stein et al., 1991), the first intron of the $\mathrm{SRK}_{3}$ gene contains an in-frame stop codon which could be used to produce a truncated SLG-like protein from an alternative transcript which retains the first intron. Evidence for the existence of such transcripts has been reported previously (Stein et al., 1991). RACE-PCR (rapid amplification of cDNA ends by PCR; Frohman et al., 1988) was used to identify polyadenylation sites at the $3^{\prime}$ end of the $S R K_{3}$ gene. Three alternative polyadenylation sites were identified spread over a region of $130 \mathrm{bp}$. The deduced amino acid sequence of the $\mathrm{SRK}_{3} S$ domain is highly similar to $\mathrm{SLG}_{3}$ (82.6\% similarity, Figure 1a). Comparison with other genes in the database indicated that $S L G_{3}$ and $S R K_{3}$ are more 
similar to class I than to class II $S$ locus genes, for example, the deduced amino acid sequence of $\mathrm{SLG}_{3}$ is $84.6 \%$ similar to the class $\mid \mathrm{SLG}_{6}$ protein but only $64.4 \%$ similar to the class II $S \mathrm{SG}_{2}$ protein.

The sequence data obtained for the $\mathrm{SRK}_{3}$ gene included 1090 bp upstream of the ATG initiation codon. This sequence was compared with the promoter region of the $S R K_{63}$ gene and a highly conserved region $(74.6 \%$ identical) was identified extending $540 \mathrm{bp}$ upstream of the ATG initiation codon (Figure 2). No significant sequence similarity was found upstream of this region. Alignment of the $\mathrm{SRK}_{3}$ promoter sequence with the promoter regions of the $S L G_{13}$ and an $S L R 1$ ( $S$ locus related) gene revealed that the conserved region of the SRK promoters includes five conserved 'boxes' identified by Dzelzkalns et al. (1993) in the promoters of other members of the $S$ gene family (Figure 2). This is consistent with the similar patterns of tissue-specific expression observed for SLG, SLR1 and SRK (Hackett et al., 1992; Sato et al., 1991; Stein et al., 1991 and see below)

\section{Transcription of the $\mathrm{SLG}_{3}$ and $\mathrm{SRK}_{3}$ genes}

RNA blot analysis was used to look at expression of $S L G_{3}$ and $S R K_{3}$ transcripts in a number of vegetative and floral tissues. A probe corresponding to the $3^{\prime}$ untranslated region of the $\mathrm{SLG}_{3}$ gene hybridized to a single band in a Southern blot of genomic DNA (see Figure $7 \mathrm{~b}$ ) indicating that it is gene-specific. This probe detected a $1.6 \mathrm{~kb}$ mRNA in stigmas (Figure 3a) but no signal was obtained with anther RNA even if the sensitivity was increased by loading up to $5 \mu \mathrm{g}$ of poly(A) ${ }^{+}$RNA (Figure 3a and data not shown). A $1246 \mathrm{bp} \mathrm{Pstl/Clal} \mathrm{fragment} \mathrm{from} \mathrm{the} \mathrm{kinase} \mathrm{domain} \mathrm{of}$ the $S R K_{3}$ cDNA was used to detect $S R K_{3}$ expression. This probe also detects a single fragment in genomic DNA digests (see Figure 7a) and is hence gene-specific. When $25 \mu \mathrm{g}$ of total RNA from a range of different tissues were electrophoresed on a gel and probed, $\mathrm{SRK}_{3}$ transcripts were detected only in stigmas (Figure $3 b$ ). If the sensitivity was increased by loading several micrograms of poly $(A)+$ RNA, SRK ${ }_{3}$ mRNA was also detected in anthers at both the unicellular and bicellular microspore stages, although at much lower abundances than in stigma (Figure $3 \mathrm{C}$ ). SRK $\mathrm{S}_{3}$ transcripts were not detected in root poly $(A)^{+}$RNA indicating that the low levels detected in anthers nonetheless result from an induction of gene expression. The $\mathrm{SRK}_{3}$ probe detects a major transcript of $3.0 \mathrm{~kb}$ in stigma RNA plus slightly less abundant transcripts of 4.1, 2.2 and 1.3 $\mathrm{kb}$. A single transcript of $2.8 \mathrm{~kb}$, slightly shorter than the major transcript in stigmas, was detected in anther RNA (Figure 3c).

Sato et al. (1991) have shown by RNA blot and $\beta$ glucuronidase reporter gene fusion experiments that the $S L G_{13}$ gene is expressed in anthers. As described above, $S L G_{3}$ mRNA was not detected in anthers by RNA blots and

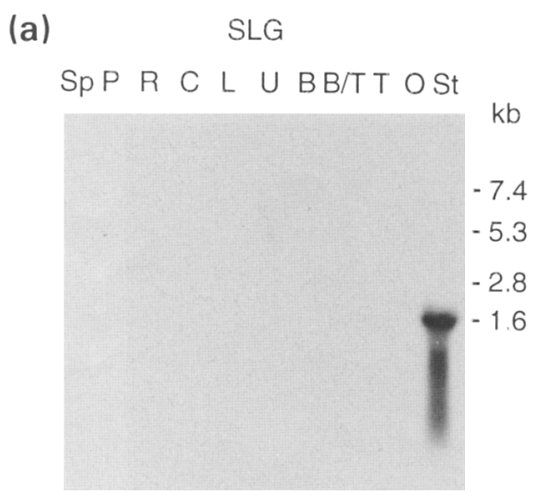

(b)
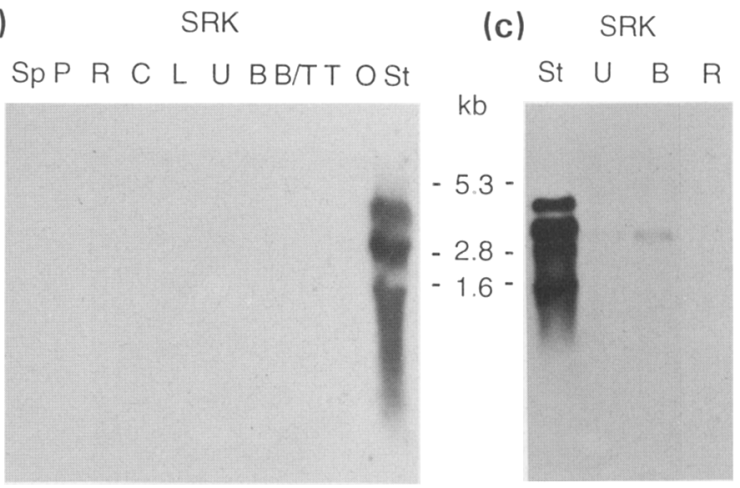

Figure 3. Analysis of expression of the $\mathrm{SLG}_{3}$ and $S R K_{3}$ genes.

RNA blot analysis of $S L G_{3}$ (a) and $S R K_{3}$ (b and c) transcripts in a range of tissues. Each lane was loaded with either $25 \mu \mathrm{g}$ of total RNA ( $a$ and $b$ ) or 2-4 $\mu \mathrm{g}$ of poly(A) ${ }^{+}$RNA (c). The gene-specific DNA probes were derived from the $3^{\prime}$ untranslated region of $S L G_{3}(a)$ or the kinase-encoding domain of $S R K_{3}$ (b and c). The autoradiographs shown in (b and c) were exposed for longer than that in (a). Comparison of the intensity of hybridization indicated that $S L G_{3}$ mRNA was at least 10 times more abundant in stigmas than the $S R K_{3}$ mRNA. Sp, sepal; $P$, petal; $R$, root; $C$, cotyledon; L, leaf; $\mathrm{U}, \mathrm{B}, \mathrm{B} / \mathrm{T}, \mathrm{T}$, anthers containing unicellular, bicellular, intermediate bicellular/ tricellular or tricellular microspores respectively; O, ovary: St, stigma. RNA size markers are shown in kilobases (kb).

we were therefore interested to determine whether $S L G_{3}$ is expressed in this organ. $S L G_{3}$ cDNAs were therefore PCR amplified and cloned from anther mRNA. DNA sequencing of three anther-derived $S L G_{3}$ CDNAs allowed the identification of errors introduced during the PCR amplification but otherwise revealed no differences between anther and pistil $S L G_{3}$ CDNAs. In order to rule out the possibility that the $S L G_{3}$ mRNA detected in anthers was due to a low level of contamination with pistil tissue, mRNA was directly extracted from single organs and the PCR amplification repeated (Figure 4). Using this proceedure, an $S L G_{3}$ PCR product was observed following amplification of CDNA from single anthers and single pistils but not from single petals. No amplification occurred if reverse transcriptase was omitted. PCR amplification of hsp70 sequences was carried out to verify that CDNA had been synthesized in the presence of reverse transcriptase (Figure 4). The degenerate oligonucleotides used are 

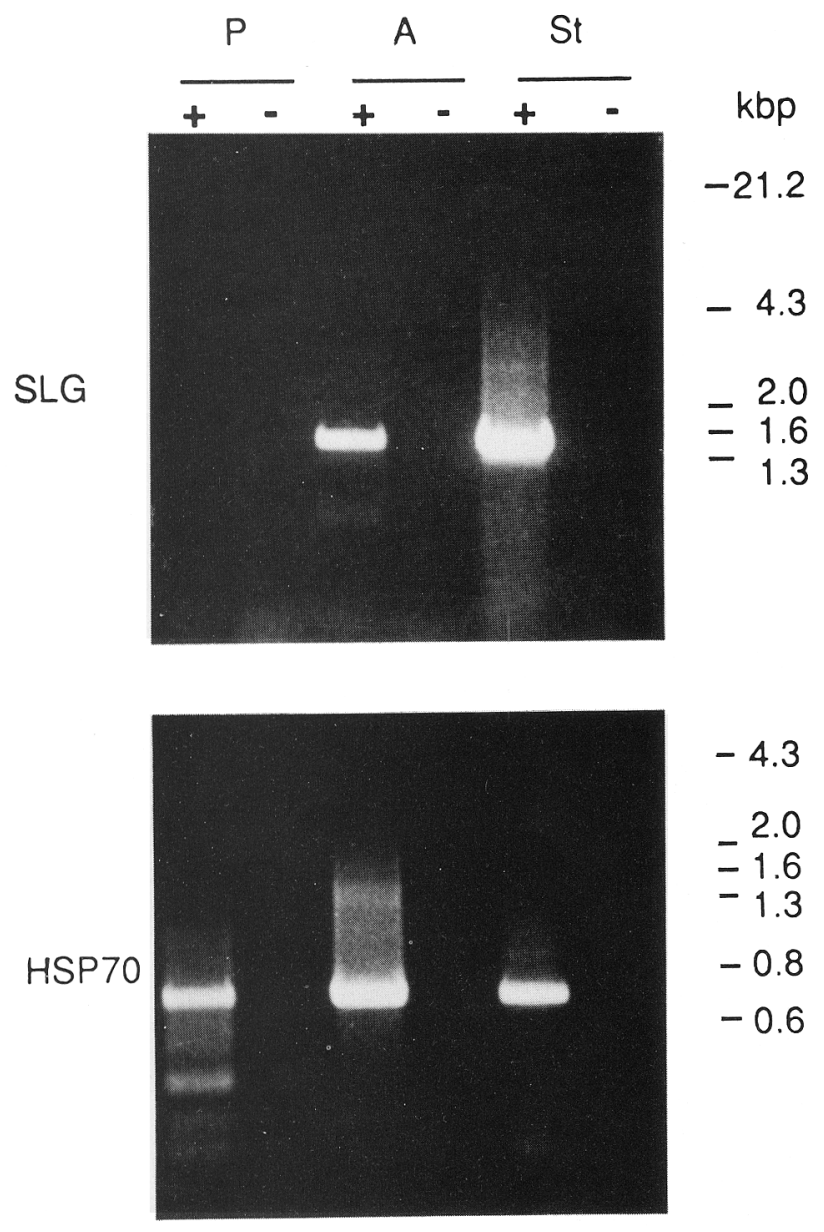

Figure 4. Detection of $S L G_{3}$ transcripts in anthers by reverse transcriptase-PCR.

Poly $(A)^{+}$RNA was extracted from a single petal (P), anther (A) or stigma (St) of the $S_{3} / S_{3}$ homozygous line and a reverse transcriptase reaction was carried out in the presence $(+)$ or absence $(-)$ of reverse transcriptase enzyme. PCR amplification was then carried out using either $S L G_{3}$ specific (upper panel) or $70 \mathrm{kDa}$ heat shock protein (hsp70)-specific (lower panel) oligonucleotides. DNA size markers are shown in kilobasepairs (kbp).

predicted to amplify products from both constitutive and heat shock-induced hsp70 genes. The results of these experiments demonstrate that the $S L G_{3}$ gene is expressed in anthers and that the $S L G_{3}$ mRNA expressed in anthers is not significantly different from that found in the pistil.

\section{Expression of $\mathrm{SLG}_{3}$ and $\mathrm{SRK}_{3}$ at the protein level}

The $\mathrm{N}$-terminal amino acid sequence of the $\mathrm{SLG}_{3}$ glycoprotein has been reported (Gaude et al., 1993). An antibody (anti-SLG $\mathrm{N}_{3} \mathrm{~N}$-ter) was raised against a peptide corresponding to this N-terminal sequence (Gaude, Rougier, Heizmann, Ockendon and Dumas, manuscript in preparation) and used to probe an immunoblot of proteins extracted from a range of tissues and separated by SDS-PAGE. Figure 5(a) shows that antibody anti-SLG ${ }_{3} \mathrm{~N}$-ter detects a triplet of bands of $60.0,61.5$ and $63.5 \mathrm{kDa}$. A similar pattern (a) SLG

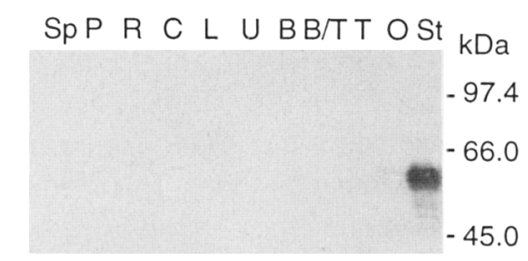

(b)

SRK

SpP R C L UBB/T T OSt

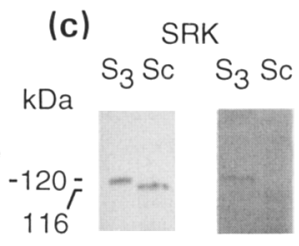

MAb 85- anti-SRK 3 36-71 C-dom

Figure 5. Detection of $\mathrm{SLG}_{3}$ and $\mathrm{SRK}_{3}$ antigen in proteins extracted from a range of tissues and separated by SDS-PAGE.

(a and b). The primary antibody was either anti-SLG $\mathrm{S}_{3} \mathrm{~N}$-ter (a) or Mab 8536-71 (b). Molecular mass markers are shown in kilodaltons (kDa). The molecular mass of the SRK protein, calculated with reference to molecular mass markers, is shown in kilodaltons ( $\mathrm{kDa}$ ) in (b). Sp, sepal; $P$, petal; $R$, root; $C$, cotyledon; $L$, leaf; U,B,B/T,T, anthers containing microspores/pollen grains at the unicellular, bicellular, intermediate bicellular/tricellular or tricellular stages, respectively; 0 , ovary; St, stigma.

(c) Detection of SRK antigen in stigmas of an $S_{3} S_{3}$ homozygous line $\left(S_{3}\right)$ and of P57 Sc (Sc) with either MAb 85-36-71 or with the anti-SRK ${ }_{3} \mathrm{C}$-dom antibody. Molecular masses of SRK proteins, calculated with reference to molecular mass markers, are shown in kilodaltons ( $\mathrm{kDa}$ ).

has been reported for other $S$ haplotypes and the different molecular mass forms have been shown to be the result of different glycoforms of the SLG protein (Isogai et al., 1987; Umbach et al., 1990). SLG glycoproteins were detected only in stigmas and hence, taking into account the sensitivity of this assay, exhibited the same tissuespecificity as the $S L G_{3}$ transcript (Figure 5).

In order to assay $\mathrm{SRK}_{3}$ expression at the protein level it was necessary to have an antibody which recognized SRK S. $_{3}$ The first 10 amino acid residues at the $\mathrm{N}$-terminus of the mature $\mathrm{SRK}_{3}$ protein (IYVNTLSSTE) are predicted to be very similar to the $\mathrm{N}$-terminus of the SLG protein (SLG-Sc) of the self-compatible B. oleracea line P57 Sc (IVVNTLSSSE; Gaude et al., 1993). A monoclonal antibody raised against this latter sequence (MAb 85-36-71; Gaude et al., 1993) was shown to recognize a protein of $120 \mathrm{kDa}$ on an immunoblot of stigma proteins separated by SDS-PAGE (Figure $5 \mathrm{~b}$ and $\mathrm{c}$ ). In addition to the $120 \mathrm{kDa}$ protein MAb 85-36-71 cross-reacted weakly with two proteins of approximately $62 \mathrm{kDa}$ in stigma extracts of the $S_{3} / S_{3}$ line (data not shown). The nature of these latter proteins is unknown. To confirm that the $120 \mathrm{kDa}$ protein corresponded 
to $\mathrm{SRK}_{3}$, a second antibody (anti-SRK ${ }_{3} \mathrm{C}$-dom) was raised against a synthetic peptide corresponding to part of the Cterminal domain of SRK 3 . This antibody was shown to recognize a fusion protein containing the kinase and $\mathrm{C}$ terminal domains of $\mathrm{SRK}_{3}$ expressed in $E$. coli (data not shown). When used as a probe against total stigma proteins, the anti-SRK ${ }_{3} \mathrm{C}$-dom antibody also recognized a protein of $120 \mathrm{kDa}$ (Figure $5 \mathrm{c}$ ) providing strong evidence that the protein detected by these two antibodies is $\mathrm{SRK}_{3}$.

Based on the gene sequence, $\mathrm{SRK}_{3}$ is predicted to possess a polypeptide backbone of $94 \mathrm{kDa}$ which may be modified by glycosylation at nine potential glycosylation sites. Following deglycosylation of stigma proteins, MAb 85-36-71 detected a protein of $94 \mathrm{kDa}$ (Figure 6a), providing further evidence that this antibody detects the $\mathrm{SRK}_{3}$ protein.

The peptide against which the anti-SRK ${ }_{3} \mathrm{C}$-dom antibody was raised corresponds to a region of the $\mathrm{C}$-terminal domain of the $\mathrm{SRK}_{3}$ protein which is predicted to be both highly antigenic and, due to the variable nature of the sequence in this region with respect to other SRK proteins, allele-specific. This prediction was supported by the fact that, using the anti-SRK ${ }_{3} \mathrm{C}$-dom antibody, a $120 \mathrm{kDa}$ protein was detected in stigma proteins of the $S_{3} / S_{3}$ line used in this study but not in stigma proteins of two lines homozygous for other $S$ haplotypes, P57 Sc (Figure $5 \mathrm{c}$ ) and $S_{25} / S_{25}$ (data not shown). MAb 85-36-71, on the other hand, recognized $120 \mathrm{kDa}$ proteins in $S_{3} / S_{3}$ and $\mathrm{P} 57 \mathrm{Sc}$ stigmas (Figure $5 \mathrm{c}$ ) but not in $S_{25} / S_{25}$ stigmas (see the parental $S_{25}$ plant in Figure 7c). This latter result indicates that, whilst MAb 853671 does not recognize all allelic forms of the SRK protein, it may be of general use for a subset of SRK alleles. For instance, based on their deduced amino acid sequences, $\mathrm{SRK}_{2}$ is predicted to possess the epitope recognized by MAb 85-36-71 whilst $\mathrm{SRK}_{6}$ is not.

\section{Membrane localization of the $\mathrm{SRK}_{3}$ protein}

SRK has been predicted to be a membrane-spanning protein based on its deduced amino-acid sequence (Stein et al., 1991). In order to test this hypothesis, we extracted proteins from pistils in a Tris- $\mathrm{HCl}, \mathrm{NaCl}$, EDTA buffer either with or without triton $X-100$ added to $3 \%$. Tantikanjana et al. (1993) have used a similar approach to show that an alternative transcript of the $S L G_{2}$ gene encodes a membrane-anchored protein. These authors, however, reported the presence of a low level of membrane-anchored $\mathrm{SLG}_{2}$ in extracts carried out in the absence of detergent and this was ascribed to the presence of membrane vesicles in the extract. A similar problem was initially encountered when extracting the $\mathrm{SRK}_{3}$ protein. An ultracentrifugation step was therefore included to remove membrane vesicles before separation of the proteins on an SDS polyacrylamide gel. Proteins in the supernatant fractions and in the pellet obtained following centrifugation of the extract in buffer (a)
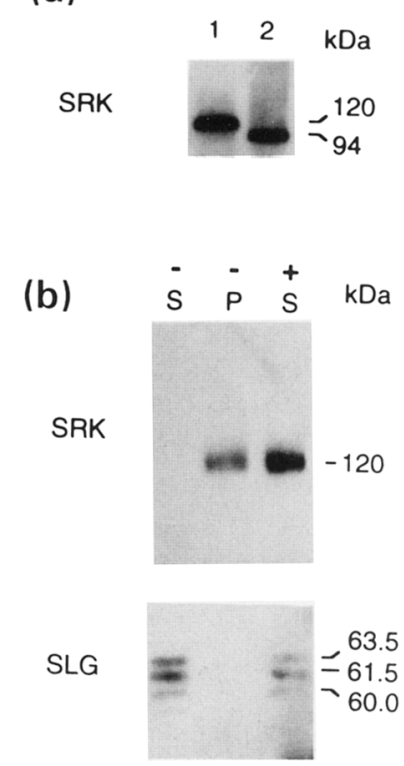

Figure 6. $S A K_{3}$ encodes a membrane-localized glycoprotein.

(a) Deglycosylation of SRK $_{3}$. Untreated (lane 1) and deglycosylated (lane 2) stigma proteins were separated by SDS-PAGE and transferred to nitrocellulose. SRK protein was detected with MAb 85-36-71.

(b) Membrane-localization of $\mathrm{SRK}_{3}$. Stigma proteins were extracted either in the presence $(t)$ or absence $(-)$ of $3 \%$ Triton $X-100$ and separated by SDS-PAGE. The primary antibody was either MAb 85-36-71 (upper panel) to detect $\mathrm{SRK}_{3}$ antigen or anti-SLG $\mathrm{N}$-ter (lower panel) to detect $\mathrm{SLG}_{3}$ antigen. The molecular masses of the $\mathrm{SRK}_{3}$ and $\mathrm{SLG}_{3}$ proteins, calculated with reference to molecular mass markers, are shown in kilodaltons (kDa). $S$, supernatant; $P$, pellet following ultracentrifugation.

without added detergent were then separated on an SDS polyacrylamide gel, blotted on to a nitrocellulose filter and probed with Mab 85-36-71. To verify that protein had been extracted under the two extraction conditions, the same immunoblot was reprobed with antibody anti-SLG $\mathrm{S}_{3} \mathrm{~N}$-ter which recognizes the $S_{L} G_{3}$ protein. Figure $6(b)$ shows that $S L G_{3}$ protein was present in the supernatant fraction of extractions carried out both in the presence and in the absence of detergent whereas the $120 \mathrm{kDa}$ protein was detected in the supernatant only when extraction was carried out in the presence of detergent. A small amount of $\mathrm{SRK}_{3}$ protein was detected in material pelleted from the minus-detergent extract by ultracentrifugation and this was presumed to be protein associated with membrane vesicles. These results indicate that $\mathrm{SRK}_{3}$ is located in the membrane.

\section{Linkage of the $\mathrm{SLG}_{3}$ and $\mathrm{SRK}_{3}$ genes to the $\mathrm{S}$ locus}

In order to confirm that the $S L G_{3}$ and $S R K_{3}$ genes described above reside at the $S$ locus, gene-specific DNA probes were used to detect restriction fragment length polymorphisms (RFLPs) in an $F_{2}$ population of 22 plants segregating for the $S_{3}$ and $S_{25}$ haplotypes. Results obtained for the two 
parental lines, an $F_{1}$ hybrid and for seven representative progeny are illustrated in Figure 7. The $\mathrm{SRK}_{3}$ kinase domain probe hybridized to an EcoRI fragment of $9.4 \mathrm{kbp}$ which was present only in DNA of plants carrying the $S_{3}$ haplotype. An identical pattern of hybridization was obtained with a probe corresponding to the $3^{\prime}$ untranslated region of $S R K_{3}$ (data not shown). The $\mathrm{SLG}_{3} 3^{\prime}$ untranslated region probe hybridized to single fragments of $4.8 \mathrm{kbp}$ and $7.2 \mathrm{kbp}$ in EcoRldigested DNA of the $S_{3} / S_{3}$ and $S_{25} / S_{25}$ homozygous lines, respectively. The $4.8 \mathrm{kbp}$ EcoRI fragment corresponds to the $S L G_{3}$ gene whilst the $7.2 \mathrm{kbp}$ EcoRI fragment presumably corresponds to the $S L G_{25}$ gene. In the $F_{1}$ and $F_{2}$ progeny, the presence or absence of these two fragments corresponded exactly with the presence or absence of the corresponding $S$ haplotype. A third EcoRl fragment of $5.9 \mathrm{kbp}$ was detected in DNA of some progeny. This fragment was presumed to be a partial digestion product of the $S L G_{25}$ gene.

We assayed for expression of the $\mathrm{SRK}_{3}$ protein in plants of the same $F_{2}$ population with the antibodies MAb 85-3671 (Figure 7c) and anti-SRK ${ }_{3} \mathrm{C}$-dom (data not shown). With both antibodies, the presence of the $120 \mathrm{kDa}$ protein in stigma extracts corresponded exactly with the presence of the $S_{3}$ haplotype. Similarily, the anti-SLG $\mathrm{N}_{3} \mathrm{~N}$-ter antibody detected $\mathrm{SLG}_{3}$ protein only in stigmas of plants shown genetically to carry the $S_{3}$ haplotype (Figure 7d). The two major glycoforms of $\mathrm{SLG}_{3}$ detected by anti-SLG $\mathrm{G}_{3} \mathrm{~N}$-ter (labelled $\delta$ and $\varepsilon$ in figure $7 \mathrm{~d}$ ) correspond to abundant stigma glycoproteins characteristic of the $S_{\mathcal{J}} / S_{3}$ line (Gaude et al., 1993). Taken together, these results demonstrate that both the $S L G_{3}$ and $S R K_{3}$ genes and expression of the $S L G_{3}$ and $\mathrm{SRK}_{3}$ proteins shows tight genetic linkage to the $S_{3}$ locus phenotype.

\section{Discussion}

\section{Characterization of the SLG and SRK genes of the $\mathrm{S}_{3}$ haplotype}

We describe here the characterization of the SLG and SRK genes of the $S_{3}$ self-incompatibility haplotype. DNA sequence analysis has shown that these two genes are most similar to genes of class I, pollen-dominant $S$ haplotypes. In addition, the deduced amino acid sequence of the $S$ domain of $\mathrm{SRK}_{3}$ is highly similar to $\mathrm{SLG}_{3} \quad 182.6 \%$; Figure 1a,) a feature typical of SLG/SRK gene pairs which originate from the same $S$ haplotype. Within each $S$ haplotype, the $S L G$ and $S R K$ genes appear to have evolved concertedly whilst the different $S$ haplotypes were diverging with respect to one another (Goring and Rothstein, 1992; Goring et al., 1993; Stein et al., 1991). The general similarity between an SRK $S$ domain and the corresponding SLG suggests that these two proteins may function in a similar manner. If this is the case, then as more SLG and SRK sequences become available, it may be possible to

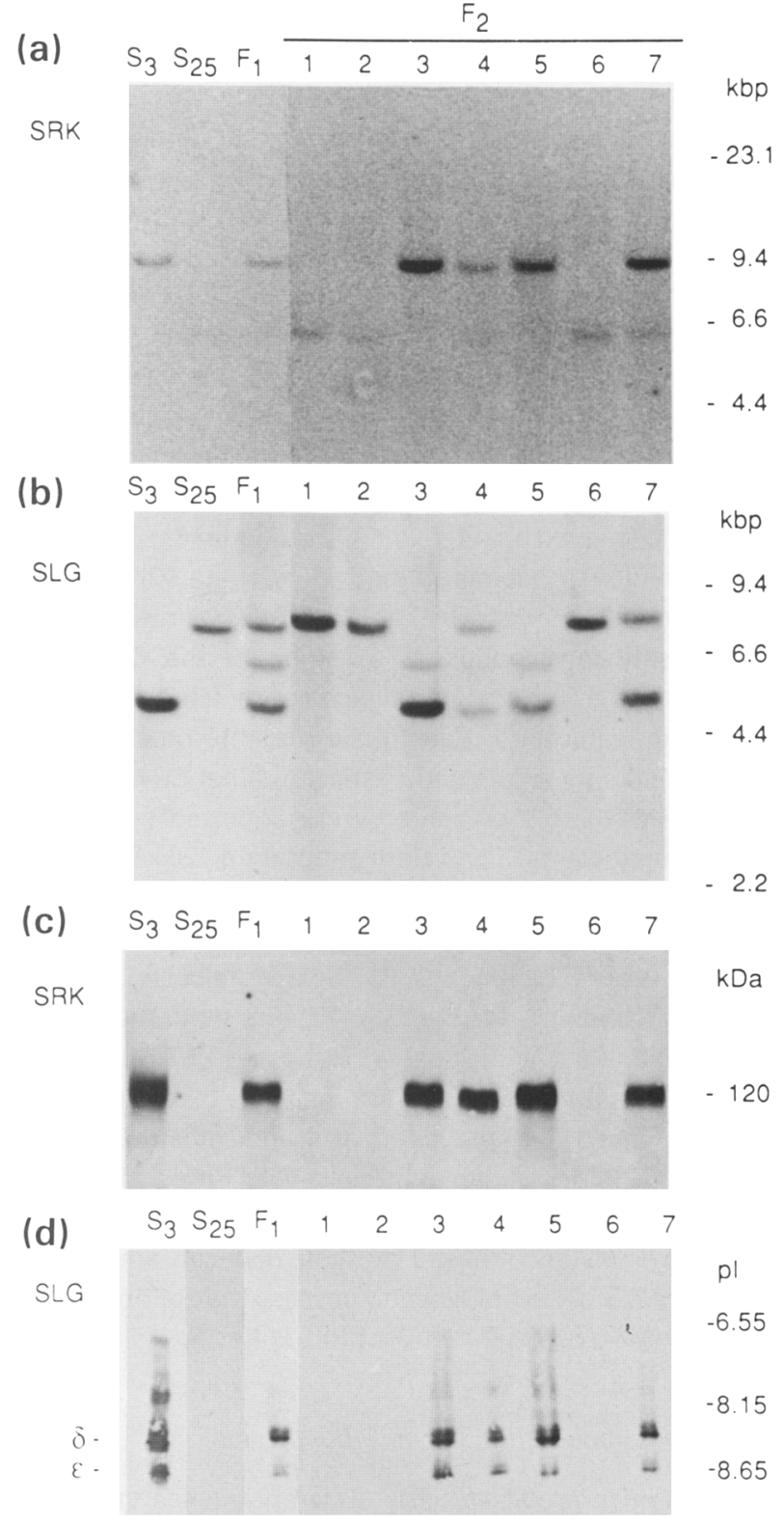

(e)

Figure 7. The $S R K_{3}$ and $S L G_{3}$ genes, and expression of the $\mathrm{SRK}_{3}$ and $\mathrm{SLG}_{3}$ proteins, are genetically linked to the $S_{3}$ locus.

(a and b) Ten micrograms of genomic DNA were digested with either EcoRV (a) or EcoRI (b) and separated on $0.8 \%$ agarose gels. After transfer to a nylon filter, the blots were hybridized with DNA probes corresponding to either the kinase-encoding domain of $S R K_{3}(a)$ or to the $3^{\prime}$ untranslated region of the $S L G_{3}$ cDNA (b).

(c and d) Detection of $\mathrm{SRK}_{3}$ (c) and $\mathrm{SLG}_{3}$ (d) antigen in stigma proteins. For detection of SRK $_{3}$ protein, stigma proteins were separated by SDS-PAGE and probed with MAb 85-36-71. For detection of $S_{L} G_{3}$ protein, stigma proteins were separated by IEF and probed with the anti-SLG $\mathrm{N}$-ter antibody. (e) $S$ locus phenotypes of the plants analysed in (a)-(d) as determined by genetic crosses. The presence of the $S_{3}$ and/or the $S_{25}$ haplotype is indicated by 3 and 25 respectively. 
identify conserved residues which are potentially important for protein function by comparing pairs of genes from the same $S$ haplotype. If, as has been suggested (Nasrallah and Nasrallah, 1993), the recognition event which leads to the self-incompatibility response results from the interaction of SRK with a ligand, it is likely that this interaction involves both a gene-specific component (common to all $S$ haplotypes) and a haplotype-specific component. This is the case for an analogous self/non-self-recognition system in Ustilago maydis (Gillissen et al., 1992). We have compared the pairs of SLG and SRK sequences of the $S$ haplotypes that have been characterized but were unable to identify haplotype-specific motifs at the primary structure (amino acid sequence) level. In particular, neither the variable region between amino acid residues 182 and 275 , which has been suggested to have a role in haplotype specificity (Nasrallah et al., 1987), nor the arrangement of potential glycosylation sites show any obvious haplotypespecificity. The identification of haplotype-specific motifs may require determination of the three-dimensional structure of these proteins.

Sequence conservation between the $\mathrm{SRK}_{3}$ promoter and promoters of other $S$ gene family members

DNA sequence extending $1090 \mathrm{bp}$ upstream of the ATG initiation codon was obtained for the $\mathrm{SRK}_{3}$ gene. Part of this sequence was shown to be highly similar to a conserved region identified in the promoters of other members of the $S$ gene family. This region is shown in Figure 2 and the five conserved elements, Box I to Box $V$, identified by Dzelzkalns et al. (1993) in SLG and SLR1 promoters are marked. The observation that there is a conservation of structure between the promoters of SRK and SLG is consistent with the similar tissue-specificity and temporal patterns of expression of the two genes. It should also be borne in mind that, as a result of the similarity between the $S L G$ and SRK promoters, genes which epistatically control expression of the $S L G$ gene may also pleiotrophically affect $S R K$ expression. Mutations in genes unlinked to the $S$ locus which lead to suppression of the self-incompatibility response (for example, see Nasrallah, 1974) apparently by suppressing SLG expression may therefore exert their effects via modification of either SLG and/or SRK expression. However, in one case (Nasrallah et al., 1992) such a mutation has been shown to affect SLG mRNA abundance without affecting SRK.

Comparison of the $S R K_{3}$ and $S R K_{63}$ promoters showed that the sequences are conserved upstream as far as $-540 \mathrm{bp}$, after which they diverge. As sufficient upstream sequence data were available only for the two $S R K$ promoters, the significance of this observation is unclear, however, it is interesting to note that Dzelzkalns et al. (1993) have shown that an $S L G_{13}$ promoter fragment extending -411 bp upstream from the initiation codon functions in an identical manner to a $3.65 \mathrm{kbp}$ promoter fragment. Thus the region conserved between the two SRK promoters may corresponds with the limits of the functional promoter.

\section{Transcription of the $\mathrm{SLG}_{3}$ and $\mathrm{SRK}_{3}$ genes}

At the mRNA level, the SLG and SRK genes of the $S_{3}$ haplotype are expressed with the same pattern as has been reported for other $S$ haplotypes (Goring and Rothstein, 1992; Sato et al., 1991; Stein et al., 1991). Both genes are expressed specifically in stigmas and anthers with mRNA levels significantly higher in stigmas compared with anthers (Figures 3 and 4). We were unable to detect $S L G_{3}$ mRNA in anther tissue by an RNA blot procedure indicating that this gene is expressed at a lower level in anthers than has been reported for the $S L G_{13}$ gene (Sato et al., 1991). $S L G_{3}$ transcripts were, however, detectable in anthers using a reverse transcriptase-PCR procedure which involved extraction of poly $(A)^{+}$RNA from single organs to avoid possible problems of contamination with stigma tissue (Figure 4). Sequencing of cDNAs corresponding to $S L G_{3}$ anther transcripts indicated that they encode a protein with an identical amino acid sequence to the stigma $S L G_{3}$. The $S R K_{3}$ kinase domain probe detected four transcripts in stigma mRNA (Figure 3c) with the same sizes and relative abundances as the transcripts detected in stigmas of an $S_{6}$ haplotype (Stein et al., 1991). Using probes corresponding to different domains of the $S R K_{6}$ gene, Stein et al. (1991) obtained data indicating that these transcripts result from alternative splicing of the $S R K_{6}$ gene. The conservation of this expression pattern in the $S_{3}$ haplotype indicates that the production of alternative transcripts and their relative abundance may be important to $S R K$ function.

\section{The $\mathrm{SRK}_{3}$ gene encodes a $120 \mathrm{kDa}$ protein in stigmas}

An immunochemical strategy, based on the use of two antibodies directed, respectively, against the $\mathrm{N}$-terminal and the $\mathrm{C}$-terminal end of $\mathrm{SRK}_{3}$, allowed the identification of a $120 \mathrm{kDa}$ protein specifically expressed in stigmas (Figure 5). Deglycosylation of the $120 \mathrm{kDa}$ protein reduces its molecular mass to $94 \mathrm{kDa}$ (Figure 6a), consistent with the predicted molecular mass for the $\mathrm{SRK}_{3}$ polypeptide and with the presence of nine potential $\mathrm{N}$-glycosylation sites in the $S$ domain. Moreover, in an $F_{2}$ population segregating for the $S_{3}$ and $S_{25}$ haplotypes, the $120 \mathrm{kDa}$ protein was detected only in stigmas of plants carrying the $S K_{3}$ gene and expressing the $S_{3}$ phenotype (Figure 7). Taken together, these data provide strong evidence that the $120 \mathrm{kDa}$ protein is an expression product of the $\mathrm{SRK}_{3}$ gene.

The protein detected in extracts of the self-compatible line P57 Sc had a smaller molecular weight than that of 
the $S_{3} / S_{3}$ homozygous line (116 kDa compared with 120 $\mathrm{kDa}$; Figure $5 \mathrm{c}$ ). Expression of this protein correlates with the presence of the $\mathrm{P} 57 \mathrm{Sc} S$ haplotype in an $\mathrm{F}_{2}$ population (Auger and Gaude, unpublished results) indicating that this protein corresponds to the SRK of the P57 Sc line. P57 Sc is a self-compatible line which possesses a class II-type SLG gene (Gaude et al., 1993). We are currently investigating the possibility that the smaller molecular weight of the SRK protein of this line is related either to the self-compatible phenotype or to the presence of a class II $S$ haplotype.

\section{The $\mathrm{SRK}_{3}$ protein is localized in the membrane}

Based on deduced amino acid sequence, SRK has been predicted to span the plasma membrane. We have shown that the $120 \mathrm{kDa}$ protein is extracted from stigma tissue only in the presence of detergent indicating that this protein is indeed localized in the membrane (Figure 6). Further work will be aimed at determining specifically whether SRK is located in the plasma membrane. In addition, the availability of two antibodies which recognize either the predicted extracellular domain or the predicted intracellular domain will provide a useful tool to confirm the predicted orientation of the SRK protein in the membrane. The observation that SRK is localized in the membrane, taken together with the demonstration that the SRK protein has a protein kinase activity (Goring and Rothstein, 1992; Stein and Nasrallah, 1993), strongly indicates that SRK functions as a membrane-spanning receptor kinase. Recently published genetic evidence that a functional SRK gene is essential for the SI response (Nasrallah et al., 1994) supports the hypothesis that the role of this receptor is as a component in the signal transduction pathway leading from recognition of self-pollen by the stigma to inhibition of the fertilization process. These data also support the hypothesis that a number of other genes which exhibit sequence homology to $S R K$ also function as receptor kinases. These genes include $A R K 1, R L K 1$ and $R L K 4$ in Arabidopsis thaliana and ZmPK1 in Zea mays (Tobias et al., 1992; Walker, 1993; Walker and Zhang,1990), genes which have been shown to be expressed in vegetative tissues and which therefore presumably play a role in processes quite different from that of $S R K$ in pollen-pistil recognition.

\section{Experimental procedures}

\section{Plant material, genetic crosses and determination of incompatibility phenotype}

The Brassica oleracea var. acephala homozygous lines P57 Si $\left(S_{3} \mid\right.$ $\mathrm{S}_{3}$ homozygous) and P57 Sc have been described (Gaude et al., 1993). Seeds of Brassica oleracea var. alboglabra homozygous for the $S_{25}$ haplotype were a gift from Dr David J. Ockendon (HRI, Wellesbourne, UK). An $F_{1}$ heterozygous plant, the result of a cross between the $S_{3} S_{3}$ and the $S_{25} S_{25}$ homozygous line, was self- fertilized to generate $F_{2}$ progeny for RFLP analysis. The incompatibility phenotype of the $F_{2}$ progeny was determined by self-pollination and by crosses to tester plants as previously described (Gaude et al., 1993).

\section{Cloning of the $\mathrm{SLG}_{3}$ cDNA}

The construction and screening of a cDNA library from mature stigmas of a $B$. oleracea var. acephala $S_{3} / S_{3}$ homozygous line (P57 Si) has been described previously (Gaude et al., 1993). The $S L G_{3}$ cDNA was one of two clones which hybridized both to a BS29-2 (SLG $\left.{ }_{29}\right)$ probe and to an oligonucleotide (5'-TCGATCAACACTITGTCG-3') based on the $\mathrm{N}$-terminal sequence of the $\mathrm{SLG}_{3}$ protein (Gaude et al., 1993). The $S L G_{3}$ CDNA was sequenced on both strands.

\section{Construction and screening of an $\mathrm{S}_{3} / \mathrm{S}_{3}$ genomic library}

Genomic DNA was extracted (Choumane and Heizmann, 1988) from $\mathrm{S}_{3} / S_{3}$ homozygous plants and a genomic library of sizefractionated Sau3A restriction fragments was constructed (Sambrook et al., 1989) in lambda Dash (Stratagene, LaJolla, CA). One million plaques were screened with a mixed probe consisting of the first $1.2 \mathrm{kbp}$ of the SLG3 cDNA and a portion of the S domain of SRK obtained by PCR amplification from genomic DNA of the $S_{3} / S_{3}$ homozygous line. Positive phage were purified by several rounds of plaque purification. Several $S L G_{3}$ clones and one $S R K_{3}$ clone were obtained. The $S L G_{3}$ genomic clone was shown to be co-linear with the $S L G_{3}$ CDNA by PCR amplification using two oligonucleotides corresponding to the $5^{\prime}$ and $3^{\prime}$ ends of the $S L G_{3}$ CDNA (5'TGGCTCGAGAGATGAAAGGCATAAGAAAAAC$3^{\prime}$ and 5'AGGGAGATCAAATTTATGTGTATTITACATGG-3', respectively). A $9 \mathrm{kbp} S \mathrm{mal}$ fragment carrying the $\mathrm{SRK}_{3}$ gene was subcloned into pBluescript-SK ${ }^{+}$(Stratagene, La Jolia, CA) and 5345 bp of DNA was sequenced. Exon/intron boundaries within the $S R K_{3}$ gene were identified by sequencing an $S R K_{3}$ cDNA obtained by PCR amplification with Pfu thermostable DNA polymerase (Stratagene, La Jolla, CA) of mature stigma cDNA using two oligonucleotides: 5'-CGACAGAACCTATGTATGGATTGCC-3' and 5'-GGCGGATCCTAAAAACAGCAAGCCAAAAAC-3'. SRK mRNA polyadenlyation sites were identified by RACE-PCR (Frohman et al., 1988).

\section{PCR cloning of $\mathrm{SLG}_{3}$ transcripts expressed in anthers}

Poly $(\mathrm{A})^{+}$RNA was extracted directly (Jakobsen et al., 1990) from a single anther or petal from flowers at the unicellular stage of microspore development or from a single mature stigma and purified by hybridization to magnetic beads carrying oligo $(\mathrm{dT})_{25}$ (Dynal AS, Oslo). A DNase digestion was carried out to remove any contaminating DNA and the poly $(A)^{+}$RNA was reverse transcribed (1st strand cDNA synthesis kit; Stratagene, La Jolla, CA). PCR amplification of $S L G_{3}$ CDNA was carried out with two specific oligonucleotides, C: 5'-TGGCTCGAGAGATGAAAGGCATAAGAAAAAC-3' and D: 5'-AGGGAGATCAAATTTATGTGTATTITACATGG-3', which prime at the $5^{\prime}$ and $3^{\prime}$ ends of the SLG 3 CDNA, respectively. Two degenerate oligonucleotides, 5'-GGGAATTCGGNGGNGGRGAYTTYGA-3' and 5'-GGGAATTCACNCCNGGYTGRTTRTC-3', were used for PCR amplification of $h s p 70$ (heat shock protein 70) cDNA. PCR amplification was carried out with AmpliTaq DNA polymerase according to the instructions of the supplier (Perkin-Elmer, NJ) for 38 cycles of $94^{\circ} \mathrm{C}$ for 1 min denaturation, $55^{\circ} \mathrm{C}$ for $1 \mathrm{~min}$ annealing and $72^{\circ} \mathrm{C}$ for 4 min extension, followed 
by a final extension for $10 \mathrm{~min}$. For cloning, PCR amplification was carried out from anther cDNA as above. The PCR product was treated with Klenow DNA polymerase to create blunt ends and phosphorylated with polynucleotide kinase. The desired product was purified by excision from an agarose gel and digestion of the agarose with Gelase (Epicentre Technologies, Madison, WI). The purified DNA was ligated into EcoRV-digested, dephosphorylated pBluescript-SK ${ }^{+}$plasmid DNA and positive clones were sequenced on both strands.

\section{DNA sequencing, RNA gel blot analysis and Southern blot analysis}

Sequencing was carried out by the dideoxy-nucleotide chain termination method (Sanger et al., 1977) using the Sequenase system (version 2.0; U.S. Biochemicals) and custom-synthesized oligonucleotides. Sequence data were analysed using Lasergene sequence analysis software (DNASTAR, London, UK). For RNA gel blots, total RNA was extracted by the method of Jackson and Larkins (1976). Cotyledons, leaves and roots were harvested from 3-week-old seedlings, all other tissues were from mature, flowering plants. The developmental stage of anthers was determined by fluorescence microscopy observation of DAPI-stained microspores. Poly $(A)^{+}$RNA was purified from $100 \mu \mathrm{g}$ batches of total RNA by hybridization to magnetic beads carrying oligo(dT) 25 (Dynal AS, Oslo, Norway). RNA was separated on formaldehyde gels and transferred to nylon filters for hybridization. For Southern blots, total genomic DNA was extracted from leaves of Brassica plants as described by Choumane and Heizmann (1988). DNA probes were prepared using a random priming DNA labelling kit (Boehringer Mannheim). Hybridizations were carried out under standard conditions and filters were washed at high stringency (Sambrook et al., 1989).

\section{Protein extraction and electrophoretic analysis}

Protein extraction, separation of proteins by isoelectric focusing (IEF) or SDS-PAGE, electrotransfer on to nitrocellulose membranes and detection of antigen with antibodies was as described previously (Gaude et al., 1993). For the identification of membranelocalized proteins, protein was extracted from stigmas in TBS buffer (20 mM Tris- $\mathrm{HCl}$ pH 8.0, $150 \mathrm{mM} \mathrm{NaCl}, 1 \mathrm{mM}$ EDTA) with or without added $3 \%(w / v)$ Triton X-100. Diluted protein extracts were centrifuged at $100000 \mathrm{~g}$ for $1 \mathrm{~h}$ at $4^{\circ} \mathrm{C}$ and then concentrated by ultrafiltration on Centricon-30 filters (Amicon, Beverly, USA) and precipitated with cold acetone before loading on an SDS polyacrylamide gel as described (Gaude et al., 1993).

\section{Deglycosylation of proteins}

Following extraction of stigma proteins in TBS buffer with $3 \%$ (w) v) of Triton $X-100$ as described above, the protein solution was diluted with 30 volumes of TBS and ultrafiltrated on a centricon 30 filter (Amicon, Beverly, USA) before lyophilization. Protein deglycosylation and subsequent recovery was performed mainly as described by Karp et al. (1982). Briefly, $250 \mu \mathrm{g}$ of lyophilized protein were deglycosylated in $50 \mu \mathrm{l}$ of TMFS/Anisole $(9 \mathrm{vol} . /$ $1 \mathrm{vol}$.) on ice for $3 \mathrm{~h}$ with magnetic stirring of the reaction mixture. After dialysis against $0.1 \mathrm{M} \mathrm{NH}_{4} \mathrm{HCO}_{3}$, deglycosylated proteins were lyophilized and resuspended in loading buffer for SDS-PAGE electrophoresis.

\section{Antibody production and immunodetection on protein blots}

The anti-SLG $\mathrm{N}_{3}$-ter and anti-SRK $\mathrm{C}_{3} \mathrm{C}$-dom antibodies were produced by injecting mice or rabbits, respectively, with peptides crosslinked to ovalbumin as described (Gaude et al., 1993). The peptides had the sequences INTLSSTESLY and SSROYDNDEWT, respectively. Antigen/antibody complexes were visualized using goat antimouse antibody or goat anti-rabbit conjugated either to alkaline phosphatase (Promega, Madison, USA) or horseradish peroxidase (Amersham) as secondary antibodies. For alkaline phosphatase development, nitroblue tetrazolium and 5-bromo-4-chloro-indolyl phosphate were used as colour development substrates. For horseradish peroxidase, ECL detection kit reagents (Amersham) were used.

\section{Expression of the $\mathrm{SRK}_{3}$ kinase domain in $\mathrm{E}$. coli}

The kinase-encoding domain of $\mathrm{SRK}_{3}$ was isolated as a $\mathrm{BcN} / \mathrm{BamHI}$ fragment of the $S R K_{3}$ CDNA described above and cloned into the BamHI site of pOE-32 (Qiagen Inc., Chatsworth, CA) to create a fusion protein containing a poly-histidine sequence followed by residues $459-850$ of $S A K_{3}$. Expression of the fusion protein in $E$. coli and purification on a nickel-nitrilo-tri-acetic acid (Ni-NTA) resin was essentially as described by the supplier (Qia-expressionist kit, Qiagen Inc., Chatsworth, CA). Briefly, fusion gene expression was induced by addition of $2 \mathrm{mM}$ isopropyl $\beta$-thiogalactoside to a $1 \mathrm{I}$ bacterial culture and the cells harvested $2 \mathrm{~h} 30 \mathrm{~min}$ later. Cells were lysed by sonication in $50 \mathrm{mM} \mathrm{NaH}{ }_{2} \mathrm{PO}_{4} \mathrm{pH} 8.0,0.3 \mathrm{M}$ $\mathrm{NaCl}, 1 \%$ Triton X-100, $1 \mathrm{mM}$ PMSF, $10 \mathrm{mM}$-mercaptoethanol, centrifuged at $15000 \mathrm{~g}$ and the supernatant mixed with Ni-NTA resin. After rinsing the resin, bound protein was eluted in the presence of imidazole and the SRK fusion protein detected by immunoblotting.

\section{Acknowledgements}

We thank Dr David J. Ockendon (HRI, Warwick, UK) for supplying us with $S_{3} / S_{3}$ tester and $S_{25} S_{25}$ Brassica lines and for help with determining the SI genotype of the P57 Si line; Dr Martin Trick (John Innes Institute, UK) for the gift of the BS29-2 clone; Dr Elizabeth Bates for the gift of hsp70-specific oligonucleotides; Monique Estienne and Richard Blanc for technical assistance and Pierre Audenis for photographic work. T.G. and P.H. are members of the Centre National de la Recherche Scientifique, J.M.C. is a member of the Institut National de la Recherche Agronomique. This work was supported by the EEC BRIDGE programme.

\section{References}

Boyes, D.C., Chen, C.H., Tantikanjana, T., Esch, J.J. and Nasrallah, J.B. (1991) Isolation of a second $S$-locus-related cDNA from Brassica oleracea: Genetic relationships between the S-locus and two related loci. Genetics, 127, 221-228.

Choumane, W. and Heizmann, P. (1988) Structure and variability of nuclear ribosomal genes in the genus Helianthus. Theor. Appl. Genet., 76, 481-489.

Dzelzkalns, V.A., Thorsness, M.K., Dwyer, K.G., Baxter, J.S., Balent, M.A., Nasrallah, M.E. and Nasrallah, J.B. (1993) Distinct cisacting elements direct pistil-specific and pollen-specific activity of the Brassica $S$ locus glycoprotein gene promoter. Plant Cell, 5, 855-863. 
Frohman, M.A., Dush, M.K. and Martin, G.R. (1988) Rapid production of full-length cDNAs from rare transcripts: Amplification using a single gene-specific oligonucleotide primer. Proc. Natl Acad. Sci. USA, 85, 8998-9002.

Gaude, T., Friry, A., Heizmann, P., Mariac, C., Rougier, M., Fobis, 1. and Dumas, C. (1993) Expression of a self-incompatibility gene in a self-compatible line of Brassica oleracea. Plant Cell, 5, 75-86.

Gillissen, B., Bergemann, J., Sandmann, C., Schroeer, B., Bölker, M. and Kahmann, R. (1992) A two-component regulatory system for self/non-self recognition in Ustilago maydis. Cell, 68, 647657.

Goring, D.R. and Rothstein, S.J. (1992) The S-locus receptor kinase gene in a self-incompatible Brassica napus line encodes a functional serine threonine kinase. Plant Cell, 4, 1273-1281.

Goring, D.R., Glavin, T.L., Schafer, U. and Rothstein, S.J. (1993) An $S$ receptor kinase gene in self-compatible Brassica napus has a 1-bp deletion. Plant Cell, 5, 531-539.

Hackett, R.M., Lawrence, M.J. and Franklin, F.C.H. (1992) A Brassica S-locus related gene promoter directs expression in both pollen and pistil of tobacco. Plant J. 2, 613-617.

Isogai, A., Takayama, S., Tsukamoto, C., Ueda, Y., Shiozawa, H., Hinata, K., Okazaki, K. and Suzuki, A. (1987) S-locus-specific glycoproteins associated with self-incompatibility in Brassica campestris. Plant Cell Physiol. 28, 1279-1291.

Jackson, A.O. and Larkins, B.A. (1976) Influence of ionic strength, $\mathrm{pH}$ and chelation of different metals on isolation of polyribosomes from tobacco leaves. Plant Physiol. 57, 5-10.

Jakobsen, K.S., Breivold, E. and Hornes, E. (1990) Purification of mRNA directly from crude plant tissues in 15 minutes using magnetic oligo dT microspheres. Nucl. Acids Res. 18, 3669.

Kandasamy, M.K., Paolillo, C.D., Faraday, J.B., Nasrallah, J.B. and Nasrallah, M.E. (1989) The $S$ locus specific glycoproteins of Brassica accumulate in the cell wall of developing stigma papillae. Devel. Biol. 134, 462-472.

Karp, R.D., Atkinson, J.P. and Shreffler, D.C. (1982) Genetic variation in glycosylation of the fourth component of murine complement. J. Biol. Chem. 257, 7330-7335.

Lalonde, B.A., Nasrallah, M.E., Dwyer, K.G., Chen, C..H., Barlow, B. and Nasrallah, J.B. (1989) A highly conserved Brassica gene with homology to the $S$-locus-specific glycoprotein structural gene. Plant Cell, 1, 249-258.

Nasrallah, J.B. and Nasrallah, M.E. (1993) Pollen-stigma signalling in the sporophytic self-incompatibility response. Plant Cell, 5, 1325-1335.

Nasrallah, J.B., Kao, T.H., Chen, C.H., Goldberg, M.L. and Nasrallah, M.E. (1987) Amino-acid sequence of glycoproteins encoded by three alleles of the S-locus of Brassica oleracea. Nature, 326, 617-619.
Nasrallah, J.B., Rundle, S.J. and Nasrallah, M.E. (1994) Genetic evidence for the requirement of the Brassica S-locus receptor kinase gene in the self-incompatibility response. Plant J. 5 , 373-384

Nasrallah, M.E. (1974) Genetic control of quantitative variation in self-incompatibility proteins detected by immunodiffusion. Genetics, 76, 45-50.

Nasrallah, M.E., Kandasamy, M.K. and Nasrallah, J.B. (1992) A genetically defined trans-acting locus regulates $S$-locus function in Brassica. Plant J. 2, 497-506.

Sambrook, J., Fritsch, E.F. and Maniatis, T. (1989) Molecular Cloning: a Laboratory Manual. Cold Spring Harbor, NY: Cold Spring Harbor Laboratory Press.

Sanger, F., Nicklen, S. and Coulson, A.R. (1977) DNA sequencing with chain termination inhibitors. Proc. Nat/ Acad. Sci. USA, 74, 5463-5467.

Sato, T., Thorness, M.K., Kandasamy, M.K., Nishio, T., Hirai, M., Nasrallah, J.B. and Nasrallah, M.E. (1991) Activity of an S-locus gene promoter in pistils and anthers of transgenic Brassica. Plant Cell, 3, 867-876.

Stein, J.C. and Nasrallah, J.B. (1993) A plant receptor-like gene, the $S$-locus receptor kinase of Brassica oleracea $L$, encodes a functional serine threonine kinase. Plant Physiol. 101, 1103-1106.

Stein, J.C., Howlett, B., Boyes, D.C., Nasrallah, M.E. and Nasrallah, J.B. (1991) Molecular cloning of a putative receptor protein kinase gene encoded at the self-incompatibility locus of Brassica oleracea. Proc. Natl Acad. Sci. USA, 88, 8816-8820.

Tantikanjana, T., Nassallah, M.E., Stein, J.C., Chen, C.H. and Nasrallah, J.B. (1993) An alternative transcript of the S-locus glycoprotein gene in a class-II pollen-recessive selfincompatibility haplotype of Brassica oleracea encodes a membrane-anchored protein. Plant Cell, 5, 657-666.

Tobias, C.M., Howlett, B. and Nasrallah, J.B. (1992) An Arabidopsis thaliana gene with sequence similarity to the $S$-locus receptor kinase of Brassica oleracea: sequence and expression. Plant Physiol. 99, 284-290.

Trick, M. and Flavell, R.B. (1989) A homozygous $S$ genotype of Brassica oleracea expresses two S-like genes. Mol. Gen. Genet. 218, 112-117.

Umbach, A.L., Lalonde, B.A., Kandasamy, M.K. Nasrallah, J.B. and Nasrallah, M.E. (1990) Immunodetection of protein glycoforms encoded by two independent genes of the self-incompatibility multigene family of Brassica. Plant Physiol. 93, 739-747.

Walker, J.C. (1993) Receptor-like protein kinase genes of Arabidopsis thaliana. Plant J. 3, 451-456.

Walker, J.C. and Zhang, R. (1990) Relationship of a putative receptor kinase from maize to the S-locus glycoproteins of Brassica. Nature, 345, 743-746. 